\title{
Environmental drivers of megafauna and hominin extinction in Southeast Asia
}

\author{
Julien Louys ${ }^{1,2^{*}}$, Patrick Roberts ${ }^{3,4^{*}}$ \\ ${ }^{1}$ Australian Research Centre for Human Evolution, Environmental Futures Research Institute, Griffith \\ University, Brisbane, 4111, Australia \\ ${ }^{2}$ College of Asia and the Pacific, The Australian National University, Canberra, 2601, Australia \\ ${ }^{3}$ Max Planck Institute for the Science of Human History, Kahlaische Strasse 10, 07745, Jena, Germany \\ ${ }^{4}$ School of Social Science, The University of Queensland, St Lucia, QLD, 4072, Brisbane, Australia \\ *Corresponding authors j.louys@griffith.edu.au, roberts@shh.mpg.de
}

\section{Summary paragraph}

Southeast Asia has emerged as an important region for understanding hominin and mammalian migrations and extinctions. High-profile discoveries show Southeast Asia was home to at least five members of the genus $\mathrm{Homo}^{1-3}$. Significant turnover in Pleistocene megafauna is linked with these hominins or climate change ${ }^{4}$, although the region is often left out of discussions of megafauna extinctions. Establishing the environmental context of hominin evolution and its association with faunal changes have long been informed by stable isotope methodologies in the traditional evolutionary core of Africa ${ }^{5,6}$. However, such studies have been largely neglected in Southeast Asia. Here, we present the first large-scale dataset of stable isotope data for Southeast Asian mammals spanning the Quaternary. Our results demonstrate that Early Pleistocene forests gave way to savannahs by the Middle Pleistocene leading to the spread of grazers and extinction of browsers, although geochronological limitations mean that not all samples can be resolved to glacial/interglacial periods. Savannahs retreated by the Late Pleistocene and completely disappeared by the Holocene, replaced by highly stratified closed canopy rainforest. This resulted in the ascendency of rainforest-adapted species, including our own, at the expense of savannah and woodland specialists, such as Homo erectus. Megafauna today are restricted to rainforests and severely threatened by anthropogenic deforestation.

\section{Main Text}

Southeast Asia, comprising northern Indochinese and southern Sundaic subregions (Fig. 1), is characterised by extensive dipterocarp rainforests which host some of the most species-rich ecosystems on Earth. Yet, the exposure of a now-submerged Sundaland continental shelf during periods of lower sea level is argued to have catalysed severe environmental change, most notably the development of a central savannah corridor stretching from Indochina to Java ${ }^{7,8}$. Supported by changes in the Inter-Tropical Convergence Zone, significantly reducing precipitation over much of Southeast Asia, the expansion of drier, grassland environments are argued to have channelled earlier members of Homo and large grazing taxa throughout much of mainland and island Southeast Asia-11. Disappearance of the corridor and expansion of the modern rainforest was proposed to have led to extinction or range reduction of many of its former travellers ${ }^{4}$. Conversely, it is also associated with population expansion of rainforest species such as the Bornean orangutan and the Asian golden cat $^{12,13}$. Given the emerging cosmopolitan nature of Pleistocene Southeast Asia, testing this hypothesis 
will make a major contribution to global understandings of how hominin taxa had different ecological tolerances or capacities ${ }^{18}$ and the role of climate change in driving megafaunal extinctions ${ }^{19}$.

Despite evidence suggesting more open environments during the Pleistocene ${ }^{7,8,16}$, the extent, and even existence, of the Southeast Asian savannah corridor remains hotly debated, with modelling and long-distance pollen data suggesting rainforest coverage even at the peak of the Last Glacial Maximum (LGM) $)^{17-21}$. Testing these propositions has been hindered by limited palaeoenvironmental data associated with local records and a lack of a widespread palaeoecological assessment. Stable carbon $\left(\delta^{13} \mathrm{C}\right)$ and oxygen $\left(\delta^{18} \mathrm{O}\right)$ isotope analyses have long been used to reconstruct major environmental events on local, continental, and global scales. Built on the principle that plants have distinct $\delta^{13} \mathrm{C}$ depending on their photosynthetic pathway, while $\delta^{18} \mathrm{O}$ varies with environmental water, research has focused on the degree to which medium-large bodied mammals associated with hominins show evidence for more humid $C_{3}$ forest and woodland ecologies versus open, drier $\mathrm{C}_{4}$ 'savannah' biomes (e.g. ref $^{22}$ ). The application of isotope analyses in Southeast Asia has been historically absent though recent studies have begun analysing fossil mammals as palaeoenvironmental indicators (Extended Data Table 1). Importantly, modern baseline data necessary to properly interpret the fossil record and to put the deep-time record of geobiology into a modern context has been almost entirely missing.

To address this deficit, we report $\delta^{13} \mathrm{C}$ and $\delta^{18} \mathrm{O}$ data for 269 modern and historical specimens representing 63 mammals found in Southeast Asia. We compare these to 644 previously published $\delta^{13} \mathrm{C}$ and $\delta^{18} \mathrm{O}$ values of fossil taxa spanning the Early Pleistocene to today. For consistency and comparability, in all cases, the $\delta^{13} \mathrm{C}$ values have been corrected to $\delta^{13} \mathrm{C}_{\text {diet }}$. Our combined dataset represents the largest compilation of $\delta^{13} \mathrm{C}$ and $\delta^{18} \mathrm{O}$ data from mammals in Asia, allowing us to examine broad trends in the distribution of $C_{3}$ and $C_{4}$ plants associated with faunal communities and hominins.

Our results show that during the Early Pleistocene, both $C_{3}$ and $C_{4}$ consumers were present in Southeast Asia (Fig. 2). However, these were unevenly distributed across the region (Extended Data Table 2), with $C_{3}$ consumers predominately found in Indochina $\left(\delta^{13} C_{\text {diet }} Q 1-Q 3:-29.3 \%\right.$ - $-26.4 \%$ ) and $C_{4}$ consumers in Sundaland $\left(\delta^{13} C_{\text {diet }} Q 1-Q 3:-20.0 \%\right.$ - $-13.3 \%$ ). The distribution of herbivores and omnivores across $\mathrm{C}_{3}$ and $\mathrm{C}_{4}$ ecosystems (Extended Data Fig. 1) was not significantly different during this period $\left(X^{2}(2, N=120)=1.95, p=0.377\right)$. By the Middle Pleistocene, Sundaland records very few $C_{3}$ consumers (Extended Data Fig. 1 and 2), with most species falling into the $C_{4}$ range and, to a lesser extent, the mixed $\mathrm{C}_{3}-\mathrm{C}_{4}$ feeder category (Q1-Q3: -15.8\%o- -13.3\%o). The beginning of this period sees a peak in $\delta^{13} C_{\text {diet }}$ (Extended Data Fig. 2) corresponding to a shift of $C_{3}$ herbivores in Indochina towards higher $\delta^{13} \mathrm{C}$ values $\left(\mathrm{X}^{2}(2, N=308)=40.754, \mathrm{p}<0.001\right)$. This appears not to have affected omnivores whose distributions across both regions remain similar to their Early Pleistocene distribution $\left(X^{2}(2, N\right.$ $=39)=0.23, p=0.893)$. Carnivores favour $C_{4}$-grazers during this time $(\bar{x}=-14.6 \%, N=7)$. By the Late Pleistocene, most Sundanese and Indochinese herbivores and omnivores were consuming predominately $\mathrm{C}_{3}$ resources ( $\overline{\mathrm{x}}_{\text {herbivore }}=-25.3 \%, \mathrm{~N}=149 ; \overline{\mathrm{x}}_{\text {omnivore }}=-22.3 \%, \mathrm{~N}=38$ ). This stands in marked contrast to the carnivores, most of whom were still found in the $C_{4}$ end of the dietary spectrum $\left(\bar{x}_{\text {carnivore }}=-16.2 \%, N=14\right)$. By the Holocene, Southeast Asian mammals were consuming $C_{3}$ diets across the entire trophic spectrum $\left(\bar{x}_{\text {herbivore }}=-25.5 \%, N=270 ; \bar{x}_{\text {omnivore }}=-23.5 \%, N=38 ; \bar{x}_{\text {carnivore }}=-24.0 \%\right.$, $N$ $=15)$.

Beyond prominent $C_{3}$ and $C_{4}$ distinctions, we also find significant $\delta^{13} \mathrm{C}$ and $\delta^{18} \mathrm{O}$ variation within $\mathrm{C}_{3}$ ecosystems. The lowest $\delta^{13} C_{\text {diet }}$ values $(<-29.0 \%$ ) correspond to closed canopy and subcanopy habitats ${ }^{23,24}$. Conversely, higher $\delta^{13} \mathrm{C}$ values $(-25.6$ to $-23.0 \%$ o occur in open canopy forests or woodlands. High $\delta^{18} \mathrm{O}$ values are also found in folivores that forage in the upper canopy, whereas those that prefer the understory have lower $\delta^{18} \mathrm{O}$ values ${ }^{25}$. In Southeast Asia, the distribution of $\delta^{13} \mathrm{C}$ and $\delta^{18} \mathrm{O}$ in browsers are significantly different across all sub-epochs (Kruskal-Wallis, $\mathrm{H}_{\mathrm{C}}=25.23, \mathrm{p}$ 
$<0.001 ; \mathrm{H}_{0}=27.34, \mathrm{p}<0.001$ ). Post-hoc analysis indicates that significant differences in environmental structure are present through time (Extended Data Fig. 3). In the Early Pleistocene, sites in Indochina have some understory browsers based on their $\delta^{13} \mathrm{C}$ values. By the Middle Pleistocene, no understory browsers are recorded and only five individuals have values consistent with closed canopies. In the Late Pleistocene, sites in northern Indochina begin to record the first clear evidence of closed canopy forests. In the Holocene, browsers in both Indochina and Sundaland are occupying closed canopy rainforests, with both regions exhibiting highly negatively skewed distributions $(-0.53$ and -0.63 , respectively). Increased forest stratification through time is suggested by the emergence of canopy specialists in the Holocene, supported by significantly higher $\delta^{18} \mathrm{O}$ amongst species that forage in the lower, mid, and upper canopies, respectively (Kruskal-Wallis, $\mathrm{H}=13.95, \mathrm{p}=0.001$ ).

The regional shifts in $C_{3}$ and $C_{4}$ consumption across all taxa and the shifts in $\delta^{13} C$ and $\delta^{18} O$ within browsing groups illustrate a common picture. Although subtle variation in atmospheric $\mathrm{CO}_{2}$ partial pressure and $\delta^{13} \mathrm{C}$ may have occurred over time, influencing interpretations of $\delta^{13} \mathrm{C}$ as exactly equivalent to forest cover, these are not enough to obfuscate the magnitude of changes observed in terms of $C_{4}$ to $C_{3}$ abundance or environmental shifts within $C_{3}$ environments ${ }^{22}$. Our data show that mixed to closed canopy forests were present in Indochina during the Early Pleistocene, while Sundaland hosted open savannah grasslands. By the beginning of the Middle Pleistocene, both regions were dominated by open savannahs, although those of Indochina were more wooded than those of Sundaland with some open forests persisting. Closed canopy forests emerged in Indochina during the Late Pleistocene while Sundaland remained largely dominated by open canopy forests. By the Holocene, both regions were home to largely closed canopy forests.

These observed shifts are consistent with global Quaternary climate models indicating a significant change at the mid-Pleistocene transition. A shift from low amplitude 41,000-year to high amplitude 100,000-year cycles between $1.25 \mathrm{Ma}$ and 700 ka were accompanied by significant decreases in sea surface temperatures, increases in ice volume, and heightened Asian aridity and monsoonal intensity ${ }^{26}$. The change in glacial cycles, recorded in the benthic oxygen isotope record, coincides with our observed peak in $\delta^{13} \mathrm{C}$ and $\delta^{18} \mathrm{O}$ values in Southeast Asian mammals (Extended Data Fig. 2). As drier conditions decreased in intensity, savannahs began to give way to forests (details in Methods). This process was further impacted at $400 \mathrm{ka}$ by the subsidence of the Sunda shelf ${ }^{27}$. This event significantly reduced exposed land and decreased albedo, leading to increased atmospheric convention and regional rainfall ${ }^{28}$. Our data shows an accelerated decrease in $\delta^{13} \mathrm{C}$ and $\delta^{18} \mathrm{O}$ at this time (Extended Data Fig. 2b, b), indicating a continued trend towards more favourable conditions for forests.

The distribution of sites suggests that, at their maximum, savannahs extended from Indochina down into Sundaland, enabling the dispersal of large-bodied grazers across this vast region. The expansion of these ecosystems coincides with the time of maximum hominin diversity in the region ${ }^{2}$. During the Middle and beginning of the Late Pleistocene, the dramatic decline of $C_{4}$ habitats occurs at a time of disappearance of almost all hominin taxa present in Southeast Asia. Seemingly, these populations were unable to flexibly shift to the expanding tropical rainforest habitats that came to dominate Southeast Asia (Table 1), highlighting their likely status as mixed savannah/woodland-specialists ${ }^{10}$. By contrast, the arrival of Homo sapiens in the region c. 72-45 ka is linked to the expanded presence of tropical lowland evergreen rainforest. Although savannah settings did perhaps persist in some patches and were almost certainly used by our species, Homo sapiens expanded its niche in Southeast Asia to make use of rich rainforest and marine habitats ${ }^{14,29}$. The ability to specialize in such environments becomes increasingly evident into the Terminal Pleistocene and Holocene ${ }^{30}$. 
Beyond hominins, these environmental shifts played a major role in mammalian turnover more broadly. During the Early Pleistocene, most mammals occupied a broad ecospace of open forests, the only exception being perissodactyls that were restricted to closed forests (Extended Data Fig. 4). The expansion of $\mathrm{C}_{4}$ environments and loss of closed forests between the Early and Middle Pleistocene saw mammals occupy one of two ecospaces - open forests or savannahs. Rodents, primates, and perissodactyls retreated to open forests while carnivores, artiodactyls, and proboscideans took advantage of the savannahs. The loss of closed forests likely had a role in the extinction of the largest ape to ever have existed Gigantopithecus blacki (Table 1). Based on stable isotope data, associated fauna, and tooth morphology, this species specialised on rainforest conditions in northern Indochina and its extinction during the Middle Pleistocene was likely driven by loss of its preferred habitats ${ }^{4}$. These changes likely also contributed to the extinction of other Early Pleistocene browsers such as Ailuropoda wulingshanensis and Sus peii (Table 1). The large-scale distribution of savannahs during the Middle Pleistocene, when most of the now island region was directly connected, produced novel faunal communities across Sundaland such as the Trinil H.K., Kedung Brubus, and Ngandong faunas, through exchange with Indochina and local endemism ${ }^{11}$.

A return shift towards denser tropical canopies from the late Middle Pleistocene onwards in turn led to extinctions of the now widely dispersed grazing specialists. Artiodactyls shift significantly towards open canopy forest environments (Extended Data Fig. 4), and this period records the last appearance of grazers such as Bubalus palaeokerabau and Duboisia santeng (this ecospace also hosts primates and rodents, unchanged from the Middle Pleistocene). However, this pales in comparison to the enormous shift in diet exhibited by proboscideans, corresponding to the loss of grazing taxa including Elephas hysundricus and Stegodon trigonocephalus (Table 1). From this point onwards, elephants and their kin became restricted to closed forests. Rhinos and tapirs return to closed forests by the Late Pleistocene, although they were impacted by loss of rainforests during the LGM, with Sumatran rhinos, for example, showing genetic decline corresponding to this period ${ }^{31}$. The Late Pleistocene sees a significant move towards forest ecosystems for carnivores and a major extinction event for the openadapted hyenas. Finally, the Holocene witnessed the persistence of major forested ecospaces, open and closed canopy forests. Primates also demonstrate a shift towards more closed forests at this time.

There is a significant positive correlation between conservation and extinction status in Southeast Asian mammals for both $\delta^{13} \mathrm{C}$ and $\delta^{18} \mathrm{O}\left(\tau_{c}=0.14, \mathrm{p}<0.001 ; \tau_{\mathrm{o}}=0.16, \mathrm{p}<0.001\right)$, indicating that the loss of drier and more open environments is associated with higher extinction risks. This correlation remains significant even if only modern species are considered; however, the trend is reversed such that rainforest-adapted taxa are correlated with higher levels of conservation risk $\left(\tau_{c}=-0.18, p<0.001\right.$; $\tau_{0}=0.09, p=0.006$ ). Thus, our data shows that Early-Middle Pleistocene megafauna extinctions affected $\mathrm{C}_{4}$ adapted taxa the most, as they faced the re-expansion of Late Pleistocene forest and the loss of the savannahs that had sustained them. Today, by contrast, rainforest species are at the greatest risk of extinction. This highlights the dominant role of environmental change in the fortunes of large bodied mammals. The modern rainforests of Southeast Asia harbour some of the most critically endangered animals in the world. They are at significant risk from overhunting and loss of habitat through deforestation ${ }^{32}$, representing an anthropogenically-influenced return to grassland ecosystems in which these rainforest taxa were notably absent. Our long-term perspective thus provides critical insights relevant to conservation priorities today. For example, orangutan (Pongo spp.) diets differ significantly across all sub-epochs (Kruskal-Wallis, $\mathrm{H}=11.11, \mathrm{p}=0.011$ ), with mean $\delta^{13} \mathrm{C}$ values the lowest during the Holocene. These changes are likely tied to increased exploitation and land clearing by people during the mid to late Holocene, driving orangutans deeper into rainforests where they are isolated and vulnerable ${ }^{33}$. 
Robust palaeoecological datasets are essential if we are to understand the changing adaptations of hominin and other megafauna during the Quaternary. While such records have long been available from Africa, they have been conspicuously absent from Southeast Asia until recently. Our results demonstrate that the coming and going of extensive savannah environments played a major role in hominin and mammalian Pleistocene biogeography, with savannah/woodland specialists being usurped by rainforest-adapted species as these habitats disappeared following the LGM. Of the high hominin diversity in the region, it was only our species, Homo sapiens, which sufficiently adapted to these changing conditions. Perhaps ironically, it is now a return to grassland conditions, with human development, plantations, and population growth as its primary driver, that stands as the greatest threat to some of the most critically endangered mammals in the world, as well as the long-term sustainability of human populations in the region and across the tropics as a whole. Work such as this helps to place these threats in their long-term context, demonstrating how, while our own species' fortunes changed for the better with the arrival of the typical endemic rainforest communities, it is now in danger of destroying them forever.

\section{References}

1. Détroit, F. et al. A new species of Homo from the Late Pleistocene of the Philippines. Nature, 568, 181-186 (2019).

2. Kaifu, Y. Archaic hominin populations in Asia before the arrival of modern humans: their phylogeny and implications for the "Southern Denisovans". Curr. Anthropol., 58(S17), S418S433 (2017).

3. Reich, D. et al. Denisova admixture and the first modern human dispersals into Southeast Asia and Oceania. Am. J. Hum. Genet., 89, 516-528. (2011).

4. Louys, J., Curnoe, D. \& Tong, H. Characteristics of Pleistocene megafauna extinctions in Southeast Asia. Palaeogeogr., Palaeoclimatol., Palaeoecol., 243, 152-173 (2007).

5. Klein, R.G. Stable carbon isotopes and human evolution. Proc. Natl. Acad. Sci., 110, 1047010472 (2013).

6. Cerling, T.E. et al. Woody cover and hominin environments in the past 6 million years. Nature, 476, 51-56 (2011).

7. Heaney, L.R. in Tropical Forests and Climate 53-61 (Springer, 1991)

8. Bird, M.I., Taylor, D. \& Hunt, C. Palaeoenvironments of insular Southeast Asia during the Last Glacial Period: a savanna corridor in Sundaland?. Quatern. Sci. Rev., 24, 2228-2242 (2005).

9. Louys, J. \& Turner, A. Environment, preferred habitats and potential refugia for Pleistocene Homo in Southeast Asia. C. R. Palevol, 11, 203-211 (2012).

10. Dennell, R. \& Roebroeks, W. An Asian perspective on early human dispersal from Africa. Nature, 438, 1099-1104 (2005).

11. Van den Bergh, G.D., de Vos, J. \& Sondaar, P.Y. The Late Quaternary palaeogeography of mammal evolution in the Indonesian Archipelago. Palaeogeogr., Palaeoclimatol., Palaeoecol., 171, 385-408 (2001).

12. Steiper, M.E. Population history, biogeography, and taxonomy of orangutans (Genus: Pongo) based on a population genetic meta-analysis of multiple loci. J. Hum. Evol., 50 509-522 (2006).

13. Patel, R.P. et al. Two species of Southeast Asian cats in the genus Catopuma with diverging histories: an island endemic forest specialist and a widespread habitat generalist. $R$. Soc. Open Sci., 3, 160350 (2016).

14. Roberts, P. et al. Isotopic evidence for initial coastal colonization and subsequent diversification in the human occupation of Wallacea. Nat. Comm., 11, 1-11 (2020). 
15. Blois, J.L., Zarnetske, P.L., Fitzpatrick, M.C. \& Finnegan, S. Climate change and the past, present, and future of biotic interactions. Science, 341, 499-504 (2013).

16. Louys, J. \& Meijaard, E. Palaeoecology of Southeast Asian megafauna-bearing sites from the Pleistocene and a review of environmental changes in the region. J. Biogeogr., 37, 14321449 (2010).

17. Raes, N. et al. Historical distribution of Sundaland's Dipterocarp rainforests at Quaternary glacial maxima. Proc. Natl. Acad. Sci., 111, 16790-16795 (2014).

18. Cannon, C. H., Morley, R. J. \& Bush, A. B. G. The current refugial rainforests of Sundaland are unrepresentative of their biogeographic past and highly vulnerable to disturbance. Proc. Natl. Acad. Sci. 106, 11188-11193 (2009).

19. Sun, X., Li, X., Luo, Y. \& Chen, X. The vegetation and climate at the last glaciation on the emerged continental shelf of the South China Sea. Palaeogeogr., Palaeoclimatol., Palaeoecol., 160, 301-316 (2000).

20. Handiani, D. et al. Tropical vegetation response to Heinrich Event 1 as simulated with the UVic ESCM and CCSM3. Clim. Past Discuss., 8, 5359-5387 (2012).

21. Chabangborn, A., Brandefelt, J. \& Wohlfarth, B. Asian monsoon climate during the Last Glacial Maximum: palaeo-data-model comparisons: LGM Asian monsoon climate. Boreas, 43, 220-242 (2014).

22. Levin, N. E. et al. Herbivore enamel carbon isotopic composition and the environmental context of Ardipithecus at Gona, Ethiopia. Geol. S. Am. S., 446, 215-235 (2008).

23. Cerling, T.E., Hart, J.A. \& Hart, T.B. Stable isotope ecology in the Ituri Forest. Oecologia, 138, 5-12 (2004).

24. Secord, R., Wing, S.L. \& Chew, A. Stable isotopes in early Eocene mammals as indicators of forest canopy structure and resource partitioning. Paleobiology, 34, 282-300 (2008).

25. Fannin, L.D. \& McGraw, W.S. 2019. Does oxygen stable isotope composition in Primates vary as a function of vertical stratification or folivorous behaviour?. Folia Primatol., 1-9 (2019).

26. Clark, P.U. et al. The middle Pleistocene transition: characteristics, mechanisms, and implications for long-term changes in atmospheric pCO2. Quat. Sci. Rev., 25, 3150-3184 (2006).

27. Sarr, A.C. et al. Subsiding Sundaland. Geology, 47, 119-122 (2019).

28. Di Nezio, P.N. et al. The climate response of the Indo-Pacific warm pool to glacial sea level. Paleoceanogr., 31, 866-894 (2016).

29. Barker G. \& Farr L. E. Archaeological Investigations in the Niah Caves, Sarawak, The Archaeology of Niah Caves, Sarawak. McDonald Institute Monographs (2016).

30. Piper, P.J. and Rabett, R.J. Hunting in a tropical rainforest: evidence from the Terminal Pleistocene at Lobang Hangus, Niah Caves, Sarawak. Int. J. of Osteoarchaeol., 19, 551-565 (2009).

31. Steiner, C.C., Houck, M.L. \& Ryder, O.A. Genetic variation of complete mitochondrial genome sequences of the Sumatran rhinoceros (Dicerorhinus sumatrensis). Conserv. Genet., 19, 397408 (2018).

32. Sodhi, N.S., Koh, L.P., Brook, B.W. \& Ng, P.K. Southeast Asian biodiversity: an impending disaster. Trends Ecol. Evol., 19, 654-660 (2004).

33. Spehar, S.N. et al. Orangutans venture out of the rainforest and into the Anthropocene. Sci. $A d v ., 4$ e1701422 (2018). 
Fig. 1: Locality map showing the biogeographic subregions examined, land extent during the Last Glacial Maximum, and the proposed extent of the 'savannah' corridor after ref'.

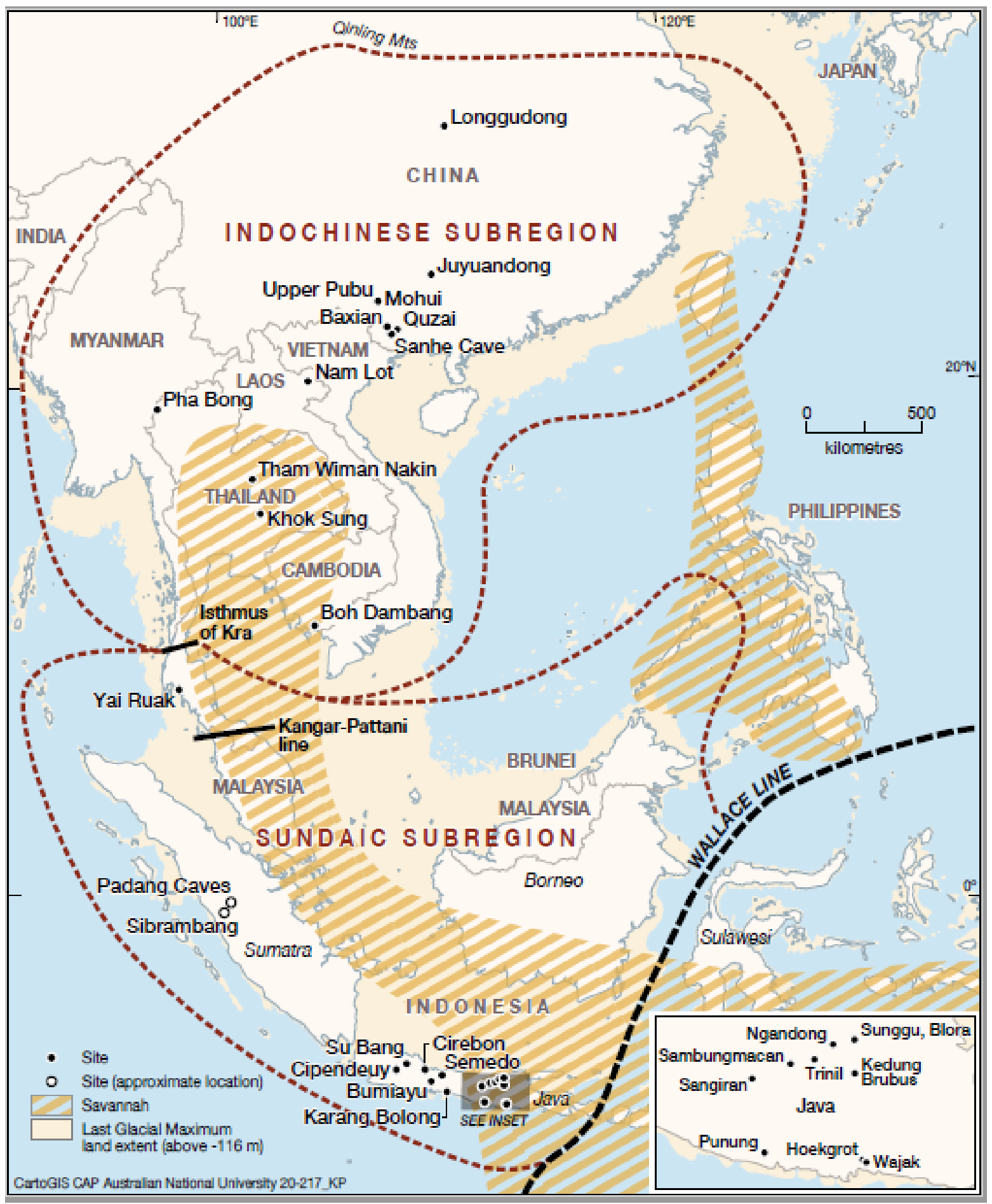


Fig. 2: Distribution of $\delta^{13} \mathrm{C}$ values across different geological sub-epochs. Green bars represent herbivores, blue omnivores, and yellow carnivores. Shaded boxes represent division between forests ( $100 \% C_{3}$ consumers) and grasslands $\left(100 \% C_{4}\right.$ consumers). All large herbivore $\delta^{13} C_{\text {enamel }}$ values were adjusted by $-14 \%$; omnivores, rodents, pigs, and primates were adjusted by $-11 \%$; Carnivora by - $9 \%$; $\delta^{13} C_{\text {hair/horn }}$ values were adjusted by $-3.1 \%$; post-1930 samples were adjusted by $1.5 \%$. VPDB, Vienna PeeDee Belemnite.

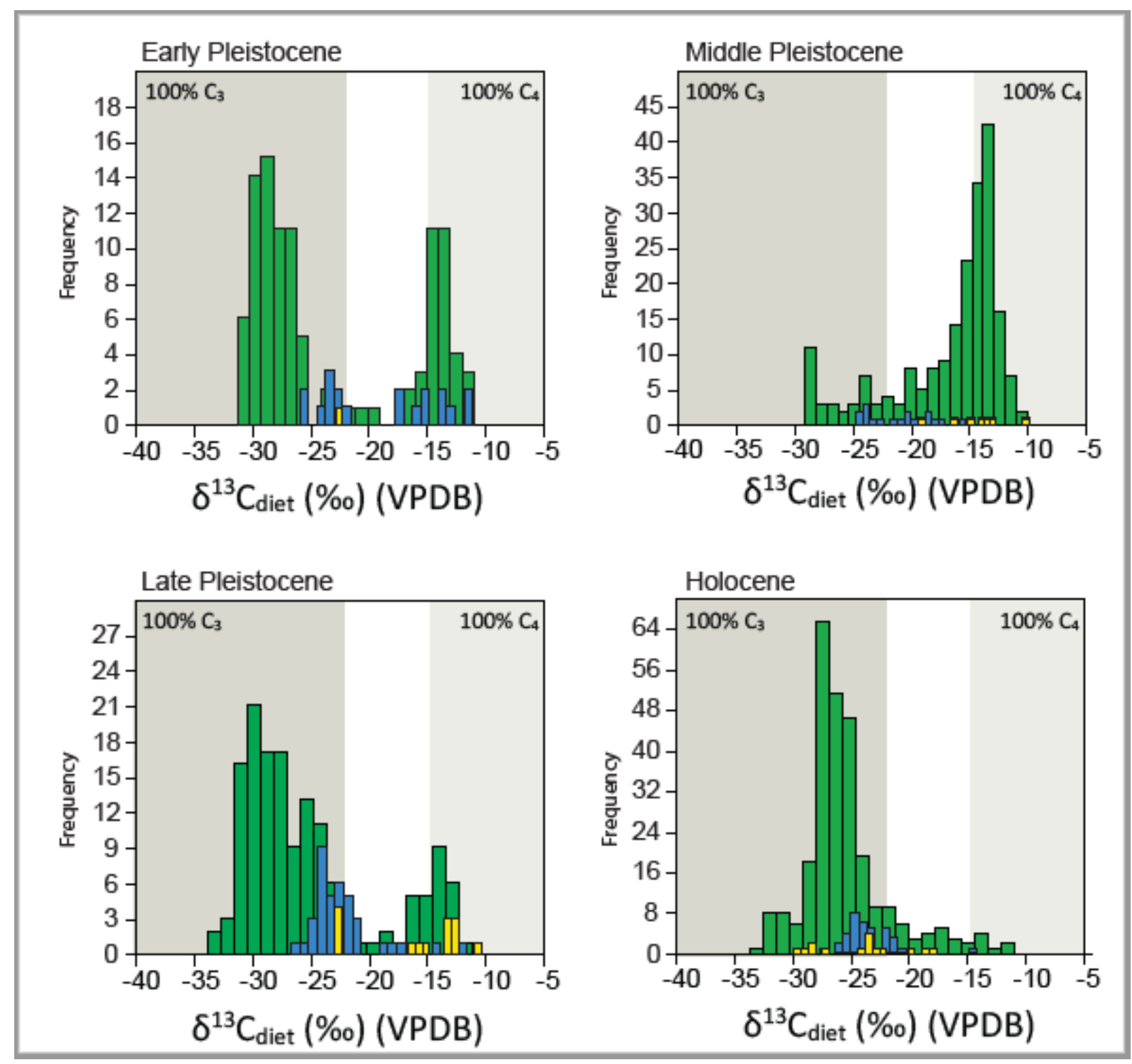

Table 1: Extinct megafauna and their last appearance dates, with corresponding site (listed in brackets) and approximate Marine Isotope Stage(s) for these sites. Average carbon and oxygen stable isotope values are provided, with $\delta^{13} \mathrm{C}<21 \%$ o considered typical of $C_{3}$ dominated ecosystems. 


\begin{tabular}{|c|c|c|c|c|c|c|c|}
\hline Taxon & $\begin{array}{l}\text { Common } \\
\text { name }\end{array}$ & $\begin{array}{l}\text { Last } \\
\text { Appearance } \\
\text { Date }\end{array}$ & $\begin{array}{l}\text { Marine } \\
\text { Isotope } \\
\text { Stage }\end{array}$ & $\begin{array}{l}\text { Mean } \\
\delta^{13} \mathrm{C}\end{array}$ & $\mathrm{N}_{\delta 13 \mathrm{C}}$ & $\begin{array}{l}\text { Mean } \\
\delta^{18} \mathrm{O}\end{array}$ & $\mathrm{N}_{\delta 180}$ \\
\hline $\begin{array}{l}\text { Ailuropoda } \\
\text { baconi }\end{array}$ & $\begin{array}{l}\text { Bacon's } \\
\text { giant panda }\end{array}$ & $\begin{array}{l}\text { 10-12 ka } \\
\text { (Gulin) }\end{array}$ & MIS1 & -25.6 & 4 & -7.0 & 4 \\
\hline $\begin{array}{l}\text { Ailuropoda } \\
\text { wulingshanensis }\end{array}$ & $\begin{array}{l}\text { Wulingshan } \\
\text { panda }\end{array}$ & $\begin{array}{l}1.2 \mathrm{Ma} \\
\text { (Sanhe) }\end{array}$ & $\begin{array}{l}\text { MIS35- } \\
40\end{array}$ & -25.7 & 1 & -7.7 & 1 \\
\hline Axis lydekkeri & $\begin{array}{l}\text { Lydekker's } \\
\text { deer }\end{array}$ & $\begin{array}{l}\text { 108-117 ka } \\
\text { (Ngandong) }\end{array}$ & MIS5 & -13.8 & 7 & -4.2 & 7 \\
\hline $\begin{array}{l}\text { Bubalus } \\
\text { palaeokerabau }\end{array}$ & & $\begin{array}{l}\text { 108-117 ka } \\
\text { (Ngandong) }\end{array}$ & MIS5 & -14.6 & 19 & -4.7 & 19 \\
\hline $\begin{array}{l}\text { Crocuta crocuta } \\
\text { ultima }\end{array}$ & $\begin{array}{l}\text { Spotted } \\
\text { hyena }\end{array}$ & $\begin{array}{l}25-18 \text { ka } \\
\text { (Boh } \\
\text { Dambang) }\end{array}$ & MIS2 & -14.8 & 12 & -6.3 & 4 \\
\hline $\begin{array}{l}\text { Duboisia } \\
\text { santeng }\end{array}$ & $\begin{array}{l}\text { Dubois' } \\
\text { antelope }\end{array}$ & $\begin{array}{l}0.54-0.43 \\
\text { Ma } \\
\text { (Trinil) }\end{array}$ & $\begin{array}{l}\text { MIS12- } \\
14\end{array}$ & -14.0 & 3 & -4.1 & 3 \\
\hline $\begin{array}{l}\text { Elephas } \\
\text { hysudrindicus }\end{array}$ & & $\begin{array}{l}\text { 108-117 ka } \\
\text { (Ngandong) }\end{array}$ & MIS5 & -15.0 & 12 & -4.6 & 12 \\
\hline $\begin{array}{l}\text { Gigantopithecus } \\
\text { blacki }\end{array}$ & & $\begin{array}{l}400-320 \text { ka } \\
\text { (Hejiang } \\
\text { Cave) }\end{array}$ & $\begin{array}{l}\text { MIS9- } \\
11\end{array}$ & -26.6 & 17 & -6.4 & 17 \\
\hline Homo erectus & & $\begin{array}{l}\text { 108-117 ka } \\
\text { (Ngandong) }\end{array}$ & MIS5 & -16.5 & 7 & -6.3 & 7 \\
\hline $\begin{array}{l}\text { Megatapirus } \\
\text { augustus }\end{array}$ & Giant tapir & $\begin{array}{l}\text { 10-12 ka } \\
\text { (Gulin) }\end{array}$ & MIS1 & -30.2 & 3 & -6.5 & 3 \\
\hline $\begin{array}{l}\text { Pachycrocuta } \\
\text { brevirostris }\end{array}$ & $\begin{array}{l}\text { Short-faced } \\
\text { hyena }\end{array}$ & $\begin{array}{l}196 \text { and } 143 \\
\text { ka } \\
\text { (Changyang) }\end{array}$ & MIS6 & -22.7 & 1 & -9.8 & 1 \\
\hline $\begin{array}{l}\text { Sinomastodon } \\
\text { bumiajuensis }\end{array}$ & & $\begin{array}{l}\text { 1.2-1.9 Ma } \\
\text { (Sangiran) }\end{array}$ & $\begin{array}{l}\text { MIS35- } \\
72\end{array}$ & -16.5 & 8 & -5.0 & 8 \\
\hline $\begin{array}{l}\text { Stegodon } \\
\text { orientalis }\end{array}$ & & $\begin{array}{l}\text { 10-12 ka } \\
\text { (Gulin) }\end{array}$ & MIS1 & -25.5 & 20 & -6.8 & 20 \\
\hline $\begin{array}{l}\text { Stegodon } \\
\text { trigonocephalus }\end{array}$ & & $\begin{array}{l}\text { 108-117 ka } \\
\text { (Ngandong) }\end{array}$ & MIS5 & -14.4 & 55 & -6.1 & 55 \\
\hline $\begin{array}{l}\text { Stegoloxodon } \\
\text { indonesicus }\end{array}$ & & $\begin{array}{l}>1.5 \mathrm{Ma} \\
\text { (Kaliglagah } \\
\text { Fm) }\end{array}$ & $>$ MIS50 & -27.7 & 5 & -5.7 & 5 \\
\hline $\begin{array}{l}\text { Sus } \\
\text { brachygnathus }\end{array}$ & & $\begin{array}{l}0.54-0.43 \\
\text { Ma } \\
\text { (Trinil) }\end{array}$ & $\begin{array}{l}\text { MIS12- } \\
14\end{array}$ & -17.8 & 3 & -6.3 & 3 \\
\hline Sus peii & & $\begin{array}{l}\text { 630-810 ka } \\
\text { (Sanhe } \\
\text { Cave) }\end{array}$ & $\begin{array}{l}\text { MIS15- } \\
20\end{array}$ & -25.8 & 1 & -7.5 & 1 \\
\hline Sus xiaozhu & & $\begin{array}{l}320-400 \text { ka } \\
\text { (Hejiang } \\
\text { Cave) }\end{array}$ & $\begin{array}{l}\text { MIS9- } \\
11\end{array}$ & -23.5 & 1 & -7.8 & 1 \\
\hline Tapirus sinensis & $\begin{array}{l}\text { Chinese } \\
\text { tapir }\end{array}$ & $\begin{array}{l}<280-88 \text { ka } \\
\text { (Lower } \\
\text { Pubu Cave) }\end{array}$ & $<$ MIS5 & -29.5 & 4 & -10.7 & 4 \\
\hline
\end{tabular}




\section{Methods}

The process of photosynthesis produces strong isotopic fractionation of ${ }^{13} \mathrm{C}$ depending on the photosynthetic pathway used by the plant ${ }^{34,35}$. There is a large and non-overlapping distinction between $C_{3}$ and $C_{4}$ plants ${ }^{36}$. Depletion is on average, $-5 \%$ in $C_{4}$ and $-19 \%$ in $C_{3}$ plants, relative to atmospheric $\delta^{13} \mathrm{CO}_{2}$ (c. $-6.5 \%$ o prior to the industrial era). This distinction has been used in the tropics and subtropics to determine the relative proportion of $C_{4}$ grassland to $C_{3}$ woodland or forest in mammalian (including hominin) diets and thus their inferred associated environments ${ }^{34-40}$. Under $\mathrm{C}_{3}$ forest settings, there is a further canopy influence on the isotopic composition of plants. Lower light levels and trapping of respired $\mathrm{CO}_{2}$ leads to an even stronger depletion in ${ }^{13} \mathrm{C}$ in soils, leaves, fruits, and therefore mammals found in subcanopy environments ${ }^{23,41,42}$. This 'canopy effect' has been observed in temperate, subtropical, and tropical forests ${ }^{42-47}$. The distribution of $\delta^{13} \mathrm{C}$ in tropical forest mammal communities has a long left tail (highly negative skew) reflecting the abundance of browsers feeding in the canopy top, gaps in the canopy, and subcanopy frugivores who have higher $\delta^{13} \mathrm{C}$ values than browsers feeding only in the subcanopy ${ }^{23-25}$.

Measurements of $\delta^{18} \mathrm{O}$ in vegetation and animals can also provide important insights into palaeoenvironments and the presence of closed canopy forests. The critical site of isotope fractionation in vegetation is the leaf, with evaporation leading to a loss of lighter ${ }^{16} \mathrm{O}$ and concomitant enrichment in ${ }^{18} \mathrm{O}\left(\mathrm{ref}^{48}\right)$. The degree of $\delta^{18} \mathrm{O}$ enrichment in leaf water is thus negatively related to relative humidity, with increasing humidity resulting in decreased $\delta^{18} \mathrm{O}$ values and vice versa ${ }^{49-51}$. Due to differences in evaporative potentials across different strata in the canopy and between different plant parts found at different heights, $\mathrm{CO}_{2}$ and vegetation $\delta^{18} \mathrm{O}$ will differ based on vertical stratification ${ }^{52-54}$. In tropical systems, $\delta^{18} \mathrm{O}$ of vegetation, recorded with high fidelity in the tissues of mammals that obtain most of their water requirements from plants, provide information on evaporative potential or source-effect of rainfall as well as the vertical structure of forests ${ }^{25,52,53,55-58}$. Notably, folivores that forage in the canopy top will have higher $\delta^{18} \mathrm{O}$ than those that prefer the subcanopy ${ }^{25}$.

Historical mammal specimens were selected for $\delta^{13} \mathrm{C}$ and $\delta^{18} \mathrm{O}$ analysis of tooth enamel from the collections of the Zoologische Staatssammlung München (ZSM), Germany, the Muséum National d'Histoire Naturelle (MNHN), Paris, France, the American Museum of Natural History (AMNH), New York, United States of America, and the Lee Kong Chian Natural History Museum (LKCNHM), Singapore. Specimens with full adult dentition in occlusion and with clear provenance and collection information were preferentially selected. In collaboration with the curatorial teams of each institution, specimens were only sampled where duplicate specimens existed for the same taxa. Sampling was done under the CITES registration of Griffith University, Australia (no. AU 062) and the Department of Archaeology, Max Planck Institute for the Science of Human History (no. DE 215-07). Specimens were identified based on existing labels within the museum collections with taxonomy updated according to latest available systematic information.

Sampled teeth were cleaned using portable air-abrasion to remove any adhering external material. Enamel powder for bulk analysis was obtained using gentle abrasion with a diamond-tipped drill along the full length of the buccal surface in order to ensure a representative measurement for the entire period of enamel formation. All enamel powder was pretreated to remove organic or secondary carbonate contaminates following established protocols. This consisted of a series of washes in $1.5 \%$ sodium hypochlorite for 60 minutes, followed by three rinses in purified $\mathrm{H}_{2} \mathrm{O}$ and centrifuging, before $0.1 \mathrm{M}$ acetic acid was added for 10 minutes, followed by another three rinses in purified $\mathrm{H}_{2} \mathrm{O}$ (as per. ref $\left.^{59,60}\right)$. When comparing the novel data presented here with that from the existing literature it is worth noting that different pretreatment protocols have been applied in each case, though for tooth 
enamel pre-treatment induced variation is limited $\left(<0.5 \%\right.$ ofor $\delta^{13} \mathrm{C}$ and $\left.\delta^{18} \mathrm{O}^{61,62}\right)$, and these differences have a negligible effect on the scale of the questions examined here ${ }^{63}$.

Following reaction with $100 \%$ phosphoric acid, gases evolved from the samples were analysed for their stable carbon and oxygen isotopic measurements using a Thermo Gas Bench 2 connected to a Thermo Delta V Advantage Mass Spectrometer at the Department of Archaeology, Max Planck Institute for the Science of Human History, Jena, Germany. $\delta^{13} \mathrm{C}$ and $\delta^{18} \mathrm{O}$ values were compared against International Standards (IAEA-603 $\left(\delta^{13} \mathrm{C}=2.5 ; \delta^{18} \mathrm{O}=-2.4\right)$; IAEA-CO-8 $\left(\delta^{13} \mathrm{C}=-5.8 ; \delta^{18} \mathrm{O}=-22.7\right)$; USGS44 $\left(\delta^{13} \mathrm{C}=-\right.$ 42.2)) and in-house standard (MERCK $\left(\delta^{13} \mathrm{C}=-41.3 ; \delta^{18} \mathrm{O}=-14.4\right)$ ). Replicate analysis of MERCK standards suggests that machine measurement error is $\mathrm{c} . \pm 0.1 \%$ o for $\delta^{13} \mathrm{C}$ and $\pm 0.2 \%$ for $\delta^{18} \mathrm{O}$. Overall measurement precision was studied through the measurement of repeat extracts from a bovid tooth enamel standard ( $n=20, \pm 0.2 \%$ ofor $\delta^{13} \mathrm{C}$ and $\pm 0.2 \%$ ) .

Fossil $\delta^{13} \mathrm{C}$ and $\delta^{18} \mathrm{O}$ values were compiled from existing published sources ${ }^{64-76}$. These cover 31 sites across Indochina and Sundaland, representing the largest compilation of stable isotope data from anywhere in Asia. $\delta^{13} \mathrm{C}$ and $\delta^{18} \mathrm{O}$ analysis of fossil tooth enamel has shown to preserve ecological distinctions back into the Miocene ${ }^{77,78}$. The bioapatite of tooth enamel has fewer substitutions, less distortion and larger crystals than that found in bone and dentine, making it more resistant to taphonomic alteration ${ }^{79,80}$. Although we have not been able to check the state of each tooth sampled in the studies we have compiled, a number of studies have studied the potential for taphonomic change in fossil enamel in hydrologically active tropical settings using chemical and physical analysis ${ }^{14,81}$. They found limited alteration to fossil enamel structure in both open air and cave contexts in South and Southeast Asia dating back to the Pleistocene and concluded there was no reason to assume alteration to the $\delta^{13} \mathrm{C}$ and $\delta^{18} \mathrm{O}$ values. Furthermore, several studies from which the compiled data were taken applied similar approaches to demonstrate taphonomic integrity ${ }^{65,73,76}$.

Where serially sampled values were provided, we calculated the mean for both carbon and oxygen isotopes for each specimen. To enable comparison of our $\delta^{13} \mathrm{C}$ dataset with existing fossil enamel $\delta^{13} \mathrm{C}$ in the literature we performed a series of data corrections. We made no adjustment for the Suess effect for specimens collected prior to 1931 as $\delta^{13} \mathrm{C} \mathrm{CO}_{2}$ in 1930 differs from pre-industrial values by just c. $0.2 \%{ }^{82}$. This is, as far as can be confidently ascertained from existing museum records, after or around the time of the death of most individuals sampled in our dataset. For specimens with known collection dates after 1930 we applied an offset of $1.5 \%$, and for modern data sourced from published sources, we followed the authors' application of this offset. Another approach is to correct modern samples using the atmospheric $\delta^{13} \mathrm{C}$ values by year, using a dataset spanning $1850-2015^{83}$ (Graven et al. 2017). The use of different corrections produced statistically indistinguishable values $(r=0.99, p<$ 0.0001 ), lending confidence to the modern $\delta^{13} \mathrm{C}$ values used in our analyses. In order to convert all existing faunal data into an estimated $\delta^{13} \mathrm{C}$ of diet, a correction was applied to all fossil and modern enamel, apatite, bone, horn, and hair samples.

Hair and horn samples were adjusted by $-3.1 \%$ following refs ${ }^{64,84,85}$. Enamel, apatite, and bone samples from both ruminant and non-ruminant large-bodied herbivores were adjusted by $-14 \%$. This corresponds to a collagen to diet offset of $\sim 5 \%$ (following ref $^{76}$ ) and a carbonate to collagen offset of between $7-8 \%$ and $9 \%$ for non-ruminants and ruminants, respectively ${ }^{85,87}$. Because they have similar carbonate to collagen offsets (wild omnivores (5.5\%), omnivorous rodents $(5.5 \%$ ), captive pigs $\left(6.0 \%\right.$ ) , hominoids $(6.0 \%)$, and cercopithecines $\left(5.9 \%\right.$ ) - see ref $\left.{ }^{87}\right)$, all omnivores, rodents, pigs, and primates in our dataset were adjusted by $-11 \%$. Several taxa in Asia belonging to the Carnivora are herbivores (e.g. giant panda, red panda). Diet-apatite offset values are determined largely by digestive physiology, with differences in metabolic breakdown, and in particular degree of fermentation, a likely explanation for differences between carnivores and herbivores ${ }^{86,88}$. Fermentation processes, in turn, 
are controlled by gut microbiota ${ }^{89}$. We assigned offset values for herbivorous Carnivora based on comparative gut microbe diversity and physiology ${ }^{90,91}$. On this basis, giant and red pandas are similar to other typical carnivores (see fig. S2 in ref ${ }^{90}$ ). Thus, all Carnivora were adjusted by $-9 \%$, as the carnivore carbonate to collagen offset is lower than those observed in other mammals ${ }^{86}$.

All statistical analyses were run in PAST ver. 2.17 $\mathrm{c}^{92}$. Univariate statistics for each geological sub-epoch and region and trophic group listed are provided in Extended Data Tables 2 and 3, respectively. In order to test whether or not the distribution of herbivores and omnivores were bimodal for the Early and Middle Pleistocene, we subjected each group (i.e. Early Pleistocene herbivores, Early Pleistocene omnivores, Middle Pleistocene herbivores, Middle Pleistocene herbivores) to a k-means cluster analysis, setting the number of clusters to two. We then counted the number of values falling into the first and second clusters, corresponding to $C_{3}$ and $C_{4}$ peaks, respectively. Division across all groups was very similar, with the division between clusters discernible in all but one case at $-20.0 \%{ }^{13} \mathrm{C}$. The only exception was the Middle Pleistocene herbivores, where the division occurred between $-19.3 \%$ and $-19.5 \%$. Full counts were used in the $X^{2}$ test (Extended Data Table 4). For consistency, we use a cutoff at $-20.0 \%$ across all groups; however, even when using the value of $-19.4 \%$ or Middle Pleistocene herbivores, they are still significantly different than their Early Pleistocene counterparts (X2(2, N=208) $=48.195, \mathrm{p}<0.001$ ).

Each epoch and sub-epoch of the Quaternary samples vastly different temporal scales and includes different numbers of glacial/interglacial cycles. Thus, grouping sites by geological group may mask or extenuate vegetation trends that are not reflective of the past 2.6 million years. In order to examine long term trends in $\delta^{13} \mathrm{C}$ and $\delta^{18} \mathrm{O}$ through the Quaternary, for sites with published age estimations (Extended Data Table 5), we calculated the average $\delta^{13} \mathrm{C}$ and $\delta^{18} \mathrm{O}$ values across all taxa for each site. Next, we assigned each site to successive time bins of equal duration spanning the Pleistocene. We examined time bins under three different geochronological scenarios related to the range of ages available for each site: (i) the minimum age of the site; (ii) the median age; and (iii) the maximum age. The number of time bins equalled the smallest division of the Quaternary that included at least one site in each bin. This resulted in seven bins of 321 ka duration for minimum ages; six bins of 428 ka for median age; and five bins of 513.8 for maximum ages. We applied a Locally Weighted Scatterplot Smoothing Spline ${ }^{93,94}$ with a smoothing factor set at 0.9. The $95 \%$ confidence interval for the curve was based on 999 random replicates using resampling of residuals ${ }^{92}$. We compared our results to the Lisiecki Raymo benthic oxygen isotope stack ${ }^{95}$ adjusted to the same temporal scale.

Most sites in Southeast Asia are derived from Late Pleistocene cave deposits, so there is unevenness in temporal sampling across the Quaternary, and/or they have poor constraints on their geological ages. At the extreme, geochronological constraints of these vertebrate deposits make it impossible to exclude the possibility that the fossils are sampling dry or wet states in some unexpected way, such that the patterns we observe could represent artefacts of taphonomic or sampling biases rather than broad environmental changes. Taphonomic bias could result from a restriction of fossil accumulation in caves to dry phases, as has been observed in South Africa for example ${ }^{96}$. Sampling bias could include the collection or analysis of only certain taxa from deposits. However, the possibility that the pattern we observe is artefactual can be discounted for several reasons. First, regarding taphonomy, low $\delta^{13} \mathrm{C}$ values are recovered from samples from both cave and open-air sites (e.g. Baxian and Cipeundeuy, respectively), and equally, higher $\delta^{13} \mathrm{C}$ values have are also recovered from both types of sites (e.g. Khok Sung and Pha Bong). Second, regarding sampling, several taxa, including the most commonly represented in our dataset (i.e. bovids and cervids), span the range of $\delta^{13} \mathrm{C}$ values of rainforest and savannah. Third, taphonomic and sampling biases would need to be structured in such a way that they provide a peak in $\delta^{13} \mathrm{C}$ values at the beginning of the Middle Pleistocene. There are no structural biases 
in Middle Pleistocene sites that would differentiate them from Early and Late Pleistocene sites in this way. More importantly, the patterns we observe are fully consistent with major climatic changes in Southeast Asia reported by other proxies.

The climate in Southeast Asia is governed by the position of the Inter-Tropical Convergence Zone (ITCZ), which determines where precipitation from the East Asian and the Australian-Indonesian monsoons occurs ${ }^{97}$. Changes in the position of the ITCZ during the Pleistocene have significantly impacted regional precipitation patterns and vegetation. The Mid-Pleistocene Transition initiated high amplitude 100,000-year glacial-interglacial cycles that were accompanied by heightened Asian aridity and monsoonal intensity ${ }^{26}$, corresponding with the peak in our $\delta^{13} \mathrm{C}_{\text {diet }}$ values. Following this, at the Mid-Brunhes Event between MIS13 and 11, interglacial conditions in high latitudes became warmer and more comparable to Holocene conditions ${ }^{98}$. However, cave speleothem records from Southeast Asia indicate that neither ITCZ activity nor its position responded to this event ${ }^{99,100}$, although quite variable interglacial conditions were recorded. Major changes to the ITCZ are however observed following deglaciations, where environmental changes linked to the Earth's precession cycle and insolation intensity shifted and trapped the ITCZ in a southern position, precipitating millennia-long intervals of reduced monsoon rainfall ${ }^{99,100}$. Decreasing trends in global glacial ice volume during the Late Pleistocene correspond to decreasing maximum peaks in oxygen isotopes over successive interglacials, explaining the decrease in drier conditions we observe during this time. This would have been accentuated from $\sim 400 \mathrm{ka}$ by the initiation of Sunda shelf subsidence ${ }^{27}$. This reinforces the idea that the broad trends we observe in Southeast Asian vegetation were driven by global-scale climatic changes and regional-scale geological events. Nevertheless, such events can still produce variable conditions locally, for example, the distribution of rainfall in Southeast Asia today is also strongly dependent on topographical relief as well as the position of the ITCZ ${ }^{97}$. This can cause local scale (temporal and/or spatial) environmental heterogeneity that may not be congruent with the larger scale patterns we observe. For example, some palaeoecological records show that patches of both savannah and rainforests were present in Southeast Asia during Late Pleistocene ${ }^{101-108}$. However, their impact on hominin and mammal biogeography must be understood in broader temporal and spatial environmental contexts. It is further worth noting that only palaeoecological records such as ours provide direct insights into the environments actually used by mammals and hominins, as they come from the animals themselves, rather than via indirect proxies.

For canopy specific analyses, herbivores with $\delta^{13} \mathrm{C}$ values less than $-23 \%$ were considered to belong to the browsing trophic group. Browsers were further subdivided into subcanopy $\left(<-32 \% \circ \delta^{13} \mathrm{C}\right)$, midcanopy $\left(-32--29 \% \circ \delta^{13} \mathrm{C}\right)$, and top canopy browsers $\left(-29--25.6 \% \circ \delta^{13} \mathrm{C}\right)$. Oxygen values for these were examined to determine forest stratification, with higher $\delta 180$ predicted to occur in top canopy folivores, and lower $\delta^{18} \mathrm{O}$ in subcanopy browsers ${ }^{25}$.

Analysis of changes in isotopes across mammalian orders and trophic groups proceeded in two concurrent steps: between the same order over different periods, and between different orders in the same period. Summary statistics for the $\delta^{13} \mathrm{C}$ and $\delta^{18} \mathrm{O}$ for each of these is provided in Extended Data Table 6. Statistical significance was assessed via Kruskal-Wallis test with differences deemed significant at $\alpha=0.05$. Changes across orders are illustrated in Extended Data Fig. 4.

In order to assess the relationship between conservation risk and environmental preference, we determined the conservation status for each taxon confidently identified to species from the IUCN Red List of Threatened Species ${ }^{109}$. We determined extinction times for Southeast Asian megafauna through an extensive literature survey, with sites and dates listed in Table 1 sourced from refs ${ }^{68,72,74,110-}$ ${ }^{121}$. We calculated whether a correlation between conservation risk and extinction status, and $\delta^{13} \mathrm{C}$ and $\delta^{18} \mathrm{O}$, existed using Kendall's Tau with significance assessed at $\alpha=0.05$. In order to examine 
current threats to Southeast Asian mammal biodiversity, we examined the same dataset but removed extinct species from the list.

\section{Additional References}

34. Craig, H. The geochemistry of the stable carbon isotope. Geochim. Cosmochim. Acta, 3, 5392 (1953).

35. Smith, B. N., \& Epstein. S. Two categories of ${ }^{13} \mathrm{C} /{ }^{12} \mathrm{C}$ ratios for higher plants. Plant Physiol., 47, 380-384 (1971).

36. Tieszen, L. L. Natural variations in the carbon isotope values of plants: Implications for archaeology, ecology, and paleoecology. J. Archaeol. Sci., 18, 227-248 (1991).

37. Sponheimer, M. et al. Do 'savanna' chimpanzees consume $C_{4}$ resources?" J. Hum. Evol., 51, 128-133 (2006).

38. Sponheimer, M. et al. Isotopic evidence of early hominin diets. Proc. Natl. Acad. Sci., 110, 10513-10518 (2013).

39. Codron, J. et al. Stable isotope series from elephant ivory reveal lifetime histories of a true dietary generalist. Proc. R. Soc. B, 279, 2433-2441 (2014).

40. Crowley, B. E. et al. Extinction and ecology retreat in a community of primates." Proc. R. Soc. $B, 279,3597-3605$ (2014).

41. Farquhar, G. D., Ehleringer, J. R. \& Hubick, K. T. Carbon isotope discrimination and photosynthesis. Annu. Rev. Plant Physiol. Plant Mol. Biol. 40, 503-537 (1989).

42. van der Merwe, N. J., \& Medina, E. The canopy effect, carbon isotope ratios and foodwebs in Amazonia. J. Archaeol. Sci. 18, 249-259 (1991).

43. Pearcy, R. W. \& Pfitsch W. A. Influence of sunflecks on the $\delta^{13} \mathrm{C}$ of Adenocaulon bicolor plants occurring in contrasting forest understory microsites. Oecologia 86, 457-462 (1991).

44. Bonafini, M., Pellegrini, M. Ditchfield, P. \& Pollard A. M. Investigation of the 'canopy effect' in the isotope ecology of temperate woodlands. J. Archaeol. Sci. 40, 3926-3935 (2013).

45. Ehleringer, J. R., Rundel, P. W. \& Nagy. K. A. Stable isotopes in physiological ecology and food web research. Trends Ecol. Evol. 1, 42-45 (1986).

46. van der Merwe, N. J. \& Medina, E. Photosynthesis and ${ }^{13} \mathrm{C} /{ }^{12} \mathrm{C}$ ratios in Amazonian rainforests. Geochim. Cosmochim. Acta 53, 1091-1094 (1989).

47. Ometto, J.P.H.B. et al. The stable carbon and nitrogen isotopic composition of vegetation in tropical forests of the Amazon Basin, Brazil. Biogeochemistry 79, 251-274 (2006).

48. Gonfiantini, R., Gratziu, S. \& Tongiorgi, E. in Isotopes and Radiation in Soil Plant Nutrition Studies, 405-410 (Technical Report Series No. 206. Vienna: Isotope Atomic Energy Commission, 1965).

49. Flanagan, L. B., Comstock, J. P. \& Ehleringer, J. R. Comparison of modelled and observed environmental influences on the stable oxygen and hydrogen isotope composition of leaf water in Phaseolus vulgaris L. Plant Physiol. 96, 588-596 (1991).

50. Yakir, D., Berry, J. A. Giles, L. \& Osmond. C. B. Isotopic heterogeneity of water in transpiring leaves: Identification of the component that controls the $\delta^{18} \mathrm{O}$ of atmospheric $\mathrm{O}_{2}$ and $\mathrm{CO}_{2}$. Plant, Cell Environ. 17, 73-80 (1994).

51. Sheshshayee, M. S. et al. Oxygen isotope enrichment $(\Delta 180)$ as a measure of time-averaged transpiration rate. J. Exp. Bot. 56, 3033-3039 (2005).

52. Buchmann, N. \& Ehleringer, J.R. $\mathrm{CO}_{2}$ concentration profiles, and carbon and oxygen isotopes in $C_{3}$ and $C_{4}$ crop canopies. Agric. For. Meteorol. 89, 45-58 (1998).

53. Buchmann, N., Guehl, J.M., Barigah, T.S., Ehleringer, J.R. Interseasonal comparison of $\mathrm{CO}_{2}$ concentrations, isotopic composition, and carbon dynamics in an Amazonian rainforest (French Guiana). Oecologia, 110, 120-131 (1997). 
54. da Silveira, L., Sternberg, L., Mulkey, S.S., Wright, J. S. Oxygen isotope ratio stratification in a tropical moist forest. Oecologia, 81, 51-56 (1989).

55. McCarroll, D. \& Loader, N.J. in Isotopes in Palaeonvironmental Research 67-116 (Springer, Dordrecht, 2006).

56. Carter, M.L. \& Bradbury, M.W. Oxygen isotope ratios in primate bone carbonate reflect amount of leaves and vertical stratification in the diet. Am. J. Primatol., 78, 1086-1097 (2016).

57. Kohn, M.J., Schoeninger, M.J. \& Valley, J.W. Herbivore tooth oxygen isotope compositions: effects of diet and physiology. Geochem. Cosmochim. Acta, 60, 3889-3896 (1996).

58. Levin, N.E. et al. A stable isotope aridity index for terrestrial environments. Proc. Natl. Acad. Sci., 103, 11201 (2006).

59. Lee-Thorp, J. et al. Isotopic evidence for an early shift to $\mathrm{C} 4$ resources by Pliocene hominins in Chad. Proc. Natl. Acad. Sci., 109, 20369 (2012).

60. Roberts, P. et al. Fruits of the forest: human stable isotope ecology and rainforest adaptations in Late Pleistocene and Holocene (approximately 36 to 3 ka) Sri Lanka. J. Hum. Evol., 106, 102-118 (2017).

61. Snoeck, C. \& Pellegrini, M. Comparing bioapatite carbonate pre-treatments for isotopic measurements: Part 1 - impact on structure and chemical composition. Chem. Geol., 417, 394-403 (2015).

62. Pellegrini, M. \& Snoeck, C. Comparing bioapatite carbonate pre-treatments for isotopic measurements: Part 1 -impact on carbon and oxygen isotope compositions. Chem. Geol., 420, 88-96 (2016).

63. Jiang, Q.Y., Zhao, L.X. \& Hu, Y.W. Variations of fossil enamel bioapatite caused by different preparation and measurement protocols: a case study of Gigantopithecus fauna. Vertebrata PalAsiatica, 58, 159-168 (2020).

64. Pushkina, D., Bocherens, H., Chaimanee, Y. \& Jaeger, J.J. Stable carbon isotope reconstructions of diet and paleoenvironment from the late Middle Pleistocene Snake Cave in Northeastern Thailand. Naturwissenschaften, 97, 299-309 (2010).

65. Ma, J. al. Isotopic evidence of foraging ecology of Asian elephant (Elephas maximus) in South China during the Late Pleistocene. Quatern. Int., 443, 160-167 (2017).

66. Ma, J. et al. Ecological flexibility and differential survival of Pleistocene Stegodon orientalis and Elephas maximus in mainland southeast Asia revealed by stable isotope $(C, O)$ analysis. Quatern. Sci. Rev., 212, 33-44 (2019).

67. Bacon, A.M. et al. Nam Lot (MIS 5) and Duoi U'Oi (MIS 4) Southeast Asian sites revisited: zooarchaeological and isotopic evidences. Palaeogeogr. Palaeoclimat. Palaeoecol., 512, 132144 (2018).

68. Bacon, A.M. et al. Testing the savannah corridor hypothesis during MIS2: The Boh Dambang hyena site in southern Cambodia. Quatern. Int., 464, 417-439 (2018).

69. Suraprasit, K. et al. Late Middle Pleistocene ecology and climate in Northeastern Thailand inferred from the stable isotope analysis of Khok Sung herbivore tooth enamel and the land mammal cenogram. Quatern. Sci. Rev., 193, 24-42 (2018).

70. Suraprasit, K. et al. New fossil and isotope evidence for the Pleistocene zoogeographic transition and hypothesized savanna corridor in peninsular Thailand. Quatern. Sci. Rev., 221, 105861 (2019).

71. Bocherens, H. et al. Flexibility of diet and habitat in Pleistocene South Asian mammals: Implications for the fate of the giant fossil ape Gigantopithecus. Quatern. Int., 434, 148-155 (2017). 
72. Puspaningrum, M.R. et al. Isotopic reconstruction of Proboscidean habitats and diets on Java since the Early Pleistocene: Implications for adaptation and extinction. Quatern. Sci. Rev, 228, 106007 (2020).

73. Janssen, R. et al. Tooth enamel stable isotopes of Holocene and Pleistocene fossil fauna reveal glacial and interglacial paleoenvironments of hominins in Indonesia Quatern. Sci. Rev, 144, 145-154 (2016).

74. Wang, W. et al. Sequence of mammalian fossils, including hominoid teeth, from the Bubing Basin caves, South China. J. Hum. Evol., 52, 370-379 (2007).

75. Nelson, S.V. The paleoecology of early Pleistocene Gigantopithecus blacki inferred from isotopic analyses. Am. J. Phys. Anthropol., 155, 571-578 (2014).

76. Qu, Y. et al. Preservation assessments and carbon and oxygen isotopes analysis of tooth enamel of Gigantopithecus blacki and contemporary animals from Sahne Cave, Chongzuo, South China during the Early Pleistocene. Quatern. Int., 354, 52-58 (2014).

77. Uno, K.T. et al. Late Miocene to Pliocene carbon isotope record of differential diet change among East African herbivores. Proc. Natl. Acad. Sci., 108, 6509-6514 (2011).

78. Sponheimer, M. et al. Isotopic evidence of early hominin diets. Proc. Natl. Acad. Sci., 110, 10513-10518 (2013).

79. LeGeros, R.Z. Calcium phosphates in oral biology and medicine. Monogr. Oral Sci., 15, 109111 (1991).

80. Lee-Thorp, J.A. On isotopes and old bones. Archaeometry, 50, 925-950 (2008).

81. Roberts, P. et al. Fruits of the forest: Human stable isotope ecology and rainforest adaptations in Late Pleistocene and Holocene ( 36 to 3 ka) Sri Lanka. J. Hum. Evol., 106, 102-118 (2017).

82. Friedli, $\mathrm{H}$. et al. Ice core record of the ${ }^{13} \mathrm{C} /{ }^{12} \mathrm{C}$ ratio of atmospheric $\mathrm{CO}_{2}$ in the past two centuries. Nature, 324, 237-238 (1986).

83. Graven, $\mathrm{H}$. et al. Compiled records of carbon isotopes in atmospheric $\mathrm{CO}_{2}$ for historical simulations in CMIP6. Geosci. Model Develop., 10, 12 (2017).

84. Ambrose, S. H., \& Norr, L. in Prehistoric Human Bone, 1-37 (Springer, Berlin, Heidelberg, 1993).

85. Cerling, T.E. \& Harris, J.M. Carbon isotope fractionation between diet and bioapatite in ungulate mammals and implications for ecological and paleoecological studies. Oecologia, 120, 347-363 (1999).

86. Lee-Thorp, J.A., Sealy, J.C. \& van der Merwe, N.J., Stable carbon isotope ratio differences between bone collagen and bone apatite, and their relationship to diet. J. Archaeol. Sci., 16, 585-599 (1989).

87. Crowley, B. E. et al. Stable carbon and nitrogen isotope enrichment in primate tissues. Oecologia, 164, 611-626 (2010)

88. Kellner, C. M., \& Schoeninger, M. J. A simple carbon isotope model for reconstructing prehistoric human diet. Am. J. Phys. Anthropol., 133, 1112-1127 (2007).

89. Karasov, W. H., \& Douglas, A. E. Comparative digestive physiology. Compr. Physiol. 3, 741783 (2013).

90. Ley, R. E. et al. Evolution of mammals and their gut microbes. Science, 320, 1647-1651 (2008).

91. Furness, J. B., Cottrell, J. J., \& Bravo, D. M. Comparative gut physiology symposium: comparative physiology of digestion. J. Anim. Sci., 93, 485-491 (2015).

92. Hammer, Ø., Harper, D. A., \& Ryan, P. D. PAST: Paleontological statistics software package for education and data analysis. Palaeontol. Electron., 4, 9 (2001). 
93. Cleveland, W.S. Robust locally weighted fitting and smoothing scatterplots. J. Am. Stat. Assoc., 74, 829-836 (1979).

94. Cleveland, W.S. A program for smoothing scatterplots by robust locally weighted fitting. Am. Stat., 35, 54 (1981).

95. Lisiecki, L. E., \& Raymo M. E. A Pliocene- Pleistocene stack of 57 globally distributed benthic $\mathrm{d}^{18} \mathrm{O}$ records, Paleoceanogr., 20, PA1003 (2005).

96. Pickering, R. et al. U-Pb-dated flowstones restrict South African early hominin record to dry climate phases. Nature, 565, 226-229 (2019).

97. Chuan, G.K. in The Physical Geography of Southeast Asia, 80-93 (Oxford Uni Press, Oxford, 2005).

98. Candy, I. et al. Pronounced warmth during early Middle Pleistocene interglacials: Investigating the Mid-Brunhes Event in the British terrestrial sequence. Earth-Sci. Rev., 103, 183-196 (2010).

99. Meckler, A.N. et al. Interglacial hydroclimate in the tropical West Pacific through the Late Pleistocene. Science, 336, 1301-1304 (2012).

100. Cheng, H. et al. The Asian monsoon over the past 640,000 years and ice age terminations. Nature, 534, 640-646 (2016).

101. Maloney, B.K. \& McCormac, F.G. Palaeoenvironments of North Sumatra: a 30,000 year old pollen record from Pea Bullok. Bull. Indo-Pacific Prehist. Ass., 14, 73-82 (1996).

102. van der Kaars, W.A. \& Dam, M.A.C. A 135,000-year record of vegetational and climatic change from the Bandung area, West-Java, Indonesia. Palaeogeogr. Palaeoclimatol. Palaeoecol. 117, 55-72 (1995).

103. van der Kaars, W.A. \& Dam, M.A.C. Vegetation and climate change in West-Java, Indonesia during the last 135,000 years. Quat. Int., 37, 67-71 (1997).

104. Wurster, C. M. et al. Forest contraction in north equatorial Southeast Asia during the Last Glacial Period. Proc. Natl. Acad. Sci., 107, 15508-15511 (2010).

105. Wurster, C.M. et al. Savanna in equatorial Borneo during the late Pleistocene. Sci. Rep. 9, 1-7 (2019).

106. Dubois, N. et al. Indonesian vegetation response to changes in rainfall seasonality over the past 25,000 years. Nat. Geosci. 7, 513-517 (2014).

107. Sun, X. et al. Deep-sea pollen from the South China Sea: Pleistocene indicators of East Asian monsoon. Mar. Geol. 201, 97-118 (2003).

108. Yu, S. et al. Pollen record in the northwestern continental shelf of the South China Sea in the past $82 \mathrm{ka}$ : paleoenvironmental changes in the last glacial period. J. Asian Earth Sci. 104457 (2020).

109. IUCN 2019. The IUCN Red List of Threatened Species. Version 2019-3. http://www.iucnredlist.org. Downloaded on 6 November 2019.

110. Yang, D. et al. Researches of Ailuropoda-Stegodon Fauna from Gulin China. Chongqing Press, Chongqing (1995) (in Chinese with English abstract).

111. Turvey, S. T. et al. Holocene survival of Late Pleistocene megafauna in China: a critical review of the evidence. Quatern. Sci. Rev., 76, 156-166 (2013).

112. Jin, C. et al. Chronological sequence of the early Pleistocene Gigantopithecus faunas from cave sites in the Chongzuo, Zuojiang River area, South China. Quatern. Int., 354, 4-14 (2014).

113. Rizal, Y. et al. 2020. Last appearance of Homo erectus at Ngandong, Java, 117,000108,000 years ago. Nature, 577, 381-385.

114. Joordens, J. C. et al. Homo erectus at Trinil on Java used shells for tool production and engraving. Nature, 518, 228-231 (2015). 
115. Zhang, Y. et al. New 400-320 ka Gigantopithecus blacki remains from Hejiang cave, Chongzuo City, Guangxi, South China. Quatern. Int, 354, 35-45 (2014).

116. Han, D. \& Xu, C. in Palaeoanthropology and Palaeolithic Archaeology in the People's Republic of China, 267-289 (Academic, Orlando, 1985).

117. Lu, C., Xu, X., \& Sun, X. Re-dating Changyang Cave in Hubei province, southern China. Quatern. Int. (2020).

118. van den Bergh, G.D. et al. The Early Pleistocene terrestrial vertebrate faunal sequence of Java, Indonesia. J. Vert. Paleol. Abstr. 210 (2019).

119. Dong, W. et al. New materials of Early Pleistocene Sus from Sanhe Cave, Chongzuo, Guangxi, South China Acta. Anthropol. Sin., 32, 63-76 (2013)

120. Shao, Q. et al. Coupled ESR and U-series dating of early Pleistocene Gigantopithecus faunas at Mohui and Sanhe Caves, Guangxi, southern China. Quatern. Geochron., 30, 524528 (2015).

121. Rink, W.J., Wei, W., Bekken, D. \& Jones, H.L. Geochronology of Ailuropoda-Stegodon fauna and Gigantopithecus in Guangxi Province, southern China. Quat. Res., 69, 377-387 (2008).

122. Shao, Q. et al. Coupled ESR and U-series dating of early Pleistocene Gigantopithecus faunas at Mohui and Sanhe Caves, Guangxi, southern China. Quat. Geochron., 30, 524-528 (2015).

123. Wang, Y., Jin, C.Z. \& Mead, J.I., New remains of Sinomastodon yangziensis (Proboscidea, Gomphotheriidae) from Sanhe karst cave, with discussion on the evolution of Pleistocene Sinomastodon in South China. Quat. Int., 339, 90-96 (2014).

124. Duval, M. et al. Direct ESR dating of the Pleistocene vertebrate assemblage from Khok Sung locality, Nakhon Ratchasima Province, Northeast Thailand. Pal. Electr. 22, 1-25 (2019).

125. Li, H., Li, C. \& Kuman, K., Longgudong, an Early Pleistocene site in Jianshi, South China, with stratigraphic association of human teeth and lithics. Sci. China Earth Sci., 60, 452462 (2017).

126. Bacon, A.M. et al. Late Pleistocene mammalian assemblages of Southeast Asia: New dating, mortality profiles and evolution of the predator-prey relationships in an environmental context. Palaeogeogr. Palaeoclimat. Palaeoecol. 422, 101-127 (2015).

127. Rizal, Y. et al. Last appearance of Homo erectus at Ngandong, Java, 117,000-108,000 years ago. Nature, 577, 381-385 (2020).

128. Westaway, K.E. et al. 2007. Age and biostratigraphic significance of the Punung Rainforest Fauna, East Java, Indonesia, and implications for Pongo and Homo. J. Hum. Evol. 53, 709-717 (2020).

129. Matsu'ura, S. et al. Age control of the first appearance datum for Javanese Homo erectus in the Sangiran area. Science, 367, 210-214 (2020).

130. Sun, L. et al. Magnetochronological sequence of the early Pleistocene Gigantopithecus faunas in Chongzuo, Guangxi, southern China. Quat. Int. 354, 15-23 (2014).

131. Esposito, M., Reyss, J.L., Chaimanee, Y. \& Jaeger, J.J., U-series dating of fossil teeth and carbonates from Snake Cave, Thailand. J. Archaeol. Sci. 29, 341-349 (2002).

132. Joordens, J.C. et al. Homo erectus at Trinil on Java used shells for tool production and engraving. Nature, 518, 228-231 (2015).

133. Storm, P. et al. U-series and radiocarbon analyses of human and faunal remains from Wajak, Indonesia. J. Hum. Evol. 64, 356-365 (2013). 


\section{Data availability}

All data generated and used during this study are included in this published article (and its supplementary information files).

\section{Acknowledgements}

We thank Eleanor Hoeger, Robert Voss (American Museum of Natural History, New York), Lim Kok Peng (Lee Kong Chian Natural History Museum, Singapore), Anneke van Heteren (Zoologische Staatssammlung München), and Jacques Cuisin, Violaine Nicolas, Géraldine Véron, Joséphine Lesur, Christine Lefèvre (Muséum National d'Histoire Naturelle, Paris), for allowing access to specimens under their care. Map provided by CartoGIS Services, ANU College of Asia and the Pacific, The Australian National University, and we thank Sandy Potter and Karina Pelling. This research was supported by an Australian Research Council Future Fellowship to JL (FT160100450). PR was funded by the Max Planck Society and the European Research Council (ERC) under the European Union's Horizon 2020 research and innovation programme (grant agreement No 850709).

\section{Author contributions}

$\mathrm{JL}$ conceived this research and conducted the statistical analyses. PR performed the stable isotope analyses. Both authors contributed equally to study design, data acquisition, interpretation of data, and writing of the final manuscript.

\section{Author information}

The authors declare no competing interests. Both authors can be contacted for correspondence or material requests.

\section{Materials and Correspondence}

All accession numbers, and data generated and used during this study are included in this published article (and its supplementary information files).

Extended Data Fig. 1: Distribution of $\delta^{13} \mathrm{C}$ across the Quaternary shown with a jitter plot and corresponding Kernel density for Indochina (blue) and Sundaland (red). Kernel densities exaggerated vertically such that the peak for both provinces are equal. Shaded boxes represent division between forests (left) and grasslands (right). VPDB, Vienna PeeDee Belemnite.

Extended Data Fig. 2: Temporal trends of $\delta^{13} \mathrm{C}$ and $\delta^{18} \mathrm{O}$ under different geochronological scenarios. A) $\delta^{13} \mathrm{C}$ assuming minimum age for each site; B) $\delta^{18} \mathrm{O}$ assuming minimum age for each site; C) $\delta^{13} \mathrm{C}$ assuming median age for each site; D) $\delta^{18} \mathrm{O}$ assuming median age for each site; $\left.\mathrm{E}\right) \delta^{13} \mathrm{C}$ assuming maximum age for each site; F) $\delta^{18} \mathrm{O}$ assuming maximum age for each site. Each panel shown relative to the Lisiecki Raymo benthic oxygen isotope stack. VPDB, Vienna PeeDee Belemnite. The $95 \%$ confidence interval for each curve was based on 999 random replicates using resampling of residuals.

Extended Data Fig. 3: Distribution of $\delta^{13} \mathrm{C}$ values for browsers across (Indochina: dark green; Sundaland: light green) sites through Southeast Asia. Horizontal line represents the $-29 \%$ zone indicating the beginning of subcanopy and closed canopy environments. Long lower whiskers in the box and whisker plot, indicating a very negatively skewed distribution, are most closely associated with highly stratified forests. The boxes show the median and the lower (25\%) and upper (75\%) quartiles; the whiskers encompass the minimum and maximum values. VPDB, Vienna PeeDee Belemnite. Independent sample sizes Juyuandong $n=4$, Longudong $n=26$, Mohui $n=5$, Sanhe $n=25$, 
Semedo $n=6$, Sangiran $n=4$; Upper Pubu $n=4$, Khok Sung $n=5$; Pha Bong $n=15$; Tham Wiman Nakin $n=10$; Baxian $n=32$, Boh Damban $n=18$, Nam Lot $n=39$, Quzai $n=32$, Sibrambang $n=6$, Wajak $n=4$, Cipeundeuy $n=2$; Indochina $n=74$, Sundaland $n=158$.

Extended Data Fig. 4: Changes in mean $\delta^{13} \mathrm{C}$ and $\delta^{18} \mathrm{O}$ values for mammals classified at the ordinal level. Continuity (non-significant differences in mean) of $\delta^{13} \mathrm{C}$ within orders between epochs are illustrated with arrows at the top of each plot. Continuity between orders in a single epoch are illustrated with circles bounding similar $\delta^{13} \mathrm{C}$ means. Variation within orders and epochs indicated at 1 S.D. VPDB, Vienna PeeDee Belemnite.

Extended Data Table 1: Sites included in the analyses with corresponding sources for the isotope data.

Extended Data Table 2: Univariate statistics for each geological sub-epoch and biogeographical province.

Extended Data Table 3. Univariate statistics for each geological sub-epoch and trophic group.

Extended Data Table 4: Count data for Early and Middle Pleistocene herbivores and omnivores.

Extended Data Table 5: Age ranges for fossil sites and the time bins they were allocated to for each age modelling scenario.

Extended Data Table 6: Stable isotope values for different orders of mammals across different geological epochs of the Quaternary. 